\title{
PENGARUH PELATIHAN LADDER DRILL 90 DEGREE ROTATION DAN LADDER DRILL ALI SHUFFLE TERHADAP PENINGKATAN DAYA LEDAK OTOT TUNGKAI DAN KECEPATAN
}

\author{
Shandy Pieter Pelamonia ${ }^{1)}$, Bayu Akbar Harmono ${ }^{2)}$ \\ Pendidikan Kepelatihan Olahraga, Fakultas Keguruan dan Ilmu Pendidikan, \\ Universitas PGRI Adi Buana Surabaya \\ Email : ${ }^{\text {shandypieter.or@gmail.com }}$ \\ ²Bayuakbar346@gmail.com
}

\begin{abstract}
ABSTRAK
Kondisi fisik adalah komponen yang sangat penting dalam melakukan aktivitas olahraga baik yang bersifat prestasi atau pembelajaran. Daya ledak otot tungkai dan kecepatan merupakan komponen yang dominan dalam aktivitas olahraga seperti bola basket, sepak bola, bola voli dan bela diri. Penelitian ini adalah metode penelitian "Kuantitatif" dengan teknik eksperimen semu, penelitian yang dilakukan secara ketat untuk mengetahui sebab akibat di antara variabel. Teknik analisis data pada penelitian ini adalah untuk menguji uji normalitas ganda, uji homogenitas, dan uji hipotesis. Hasil analisis dapat diketahui bahwa nilai rerata kelompok ladder drill 90 degree rotation untuk peningkatan daya ledak ada peningkatan dari pretest $(452,507)$ dan posttest $(482,220)$ sedangkan kecepatan dari pretest $(4,4)$ dan posttest $(4,394)$. Pada kelompok ladder drill ali shuffle diketahui bahwa nilai rerata daya ledak otot tungkai ada peningkatan dari pretest $(461,269)$ dan posttest $(576,757)$, sedangkan kecepatan dari pretest $(4,364)$ dan posttest $(4,360)$. Untuk kelompok kontrol memiliki nilai rerata untuk daya ledak otot tungkai dari pretest $(450,738)$ dan posttest $(456,009)$.
\end{abstract}

Kata kunci: Ladder Drill 90 Degree Rotation, Ali Shuffle, daya ledak otot tungkai, Kecepatan

\section{ABSTRACK}

Physical condition is a very important component in sports activities while they are achievement or learning. Explosive power leg muscle and speed of motion is the dominant component in sporting activities such as basketball, soccer, volleyball, martial art. The purpose of this study was to determinate This research is a "Quantitative" research method with quasi-experimental techniques, research conducted rigorously to determine the causes and effects between variables. Data analysis techniques in this study were to test the double normality test, homogeneity test, and hypothesis testing. The results of the analysis can be seen that the mean value of the ladder drill 90 degree rotation for increased explosive power has increased from the pretest (452.507) and posttest (482.220) while the speed of the pretest (4.4) and posttest (4.394). The ladder drill ali shuffle group found that the mean value of leg muscle explosive power had increased from pretest $(461,269)$ and posttest $(576,757)$, while the speed of the pretest $(4,364)$ and posttest $(4,360)$. For the control group, the mean value for leg muscle explosive power from pretest $(450,738)$ and posttest (456,009).

Keywords: Ladder Drill 90 Degree Rotation, Ali Shuffle, Explosive Muscle Power Legs, Speed

Shandy Pieter Pelamonia. Pengaruh Pelatihan Ladder Drill 90 Degree Rotation Dan Ladder Drill Ali Shuffle Terhadap Peningkatan Daya Ledak Otot Tungkai Dan Kecepatan 
http://ejurnal.budiutomomalang.ac.id/index.php/ipjok

Jp.jok (Jurnal Pendidikan. Jasmani , Olahraga dan Kesehatan)
Volume 2, Nomor 1, Nov 2018

P-ISSN 2613-9421

E-ISSN 2654-8003

\section{PENDAHULUAN}

Kondisi fisik merupakan hal yang sangat penting untuk diperhatikan, karena kondisi fisik ini akan mempengaruhi kemampuan biomotorik atlet. (Sajoto, 1995) berpendapat bahwa kondisi fisik adalah prasyarat yang sangat diperlukan dalam usaha peningkatan prestasi seorang atlet bahkan dapat dikatakan sebagai keperluan dasar yang tidak dapat ditunda. Hal ini seirama dengan pendapat (Bompa, 2009), bahwasannya untuk mencapai prestasi ditentukan oleh empat faktor latihan, yaitu persiapan fisik, persiapan teknik, persiapan taktik, dan persiapan mental. Menurut Haryono didalam (Komang Ayu Tri Widhiyanti, 2017) Ada empat aspek latihan yang perlu diperhatikan dan dilatih secara seksama oleh atlet, yaitu (a) latihan fisik, (b) latihan teknik, (c) latihan taktik, dan (d) latihan mental.

Pelatihan fisik bertujuan untuk meningkatkan fungsi potensial yang dimiliki atlet dan mengembangkan kemampuan komponen-komponen biomotoriknya sehingga dapat mencapai suatu tujuan. Komponen-komponen kondisi fisik yang dimaksud dikemukakan sebagai berikut: 1 . kekuatan atau strength adalah komponen kondisi fisik, yang menyangkut masalah kemampuan seorang atlet pada saat mempergunakan otot-ototnya, menerima beban dalam waktu kerja tertentu, 2. daya tahan atau endurance dibedakan menjadi dua yaitu: a) daya tahan otot setempat atau local endurance, dan b) daya tahan umum atau cardiorespiratory endurance. 3.daya ledak otot atau muscular power adalah kemampuan seseorang untuk melakukan kekuatan maksimum dengan usaha yang dikerahkan dalam waktu sependekpendeknya, 4. kecepatan atau speed adalah kemampuan seseorang dalam melakukan gerakan berkesinambungan, dalam bentuk yang sama dalam waktu sesingkat-singkatnya, 5. kelentukan atau flexsibility adalah keefektifan seseorang dalam menyesuaikan dirinya, untuk melakukan segala aktivitas tubuh dengan penguluran seluas-luasnya, terutama oto-otot, ligamen-ligamen di sekitar persendian, 6. keseimbangan atau balance adalah kemampuan seseorang mengendalikan organ-organ syaraf ototnya, selama melakukan gerak-gerak yang cepat, denga perubahan letak titik-titik berat badan yang cepat pula, baik dalam keadaan statis maupun lebih-lebih dalam gerak dinamis, 7. koordinasi atau coordination adalah kemampuan seseorang dalam mengintegrasikan gerakan yang berbeda ke dalam suatu pola gerakan tunggal secara efektif, 8. kelincahan atau agility adalah kemampuan seseorang dalam merubah arah, dalam posisi di arena tertentu, 9. ketepatan atau accuracy adalah kemampuan seseorang dalam mengendalikan gerakgerak bebas, terhadap suatu sasaran, (Sajoto, 1988).

Dari komponen-komponen kondisi fisik di atas peneliti ingin fokus pada daya ledak otot atau muscular powerdan kecepatan dengan membandingkan bentuk latihan yang dipakai untuk meningkatkan daya ledak 
http://ejurnal.budiutomomalang.ac.id/index.php/jpjok

Jp.jok (Jurnal Pendidikan. Jasmani , Olahraga dan Kesehatan)
Volume 2, Nomor 1, Nov 2018

P-ISSN 2613-9421

E-ISSN 2654-8003

otot tungkai dan kecepatan. Daya ledak merupakan kemampuan otot bekerja dengan cepat dan mendadak, ini biasanya dilakukan oleh pelari jarak pendek dan olahraga yang membutuhkan gerakan-gerakan cepat dan mendadak (Roesdiyanto dan Budiwanto, 2008). Daya ledak merupakan suatu unsur diantara unsur-unsur komponen kondisi fisik yaitu kemampuan biomotorik manusia, yang dapat ditingkatkan sampai batas-batas tertentu dengan melakukan latihan-latihan tertentu yang sesuai dengan cabang olahraga, diantaranya beberapa cabang olahraga yang membutuhkan daya ledak otot tungkai adalah bolavoli, basket, bulutangkis, serta beberapa cabang olahraga bela diri.

Untuk menunjang pergerakan yang cepat dalam sebuah aktivitas olahraga di butuhkan kelincahan yang baik. Sesuai dengan pendapat (Young, 2001) yang menyatakan bahwa disaat berolahraga kelincahan berperan penting untuk merubah arah, baik untuk mengejar atau menghindari lawan serta menigkatkan reaksi).

Dalam beberapa tahun terakhir telah dikembangkan suatu metode pelatihan yang sangat menyenangkan dengan menggunakan alat yang esensial menyerupai tangga dan berfungsi untuk mengajarkan keterampilan gerakan dikenal dengan istilah ladder drill, yaitu suatu bentuk pelatihan yang sangat baik untuk meningkatkan kecepatan, koordinasi dan kelincahan kaki secara keseluruhan (Tsivkin, 2011). Ditambahkan oleh (Bolton, 2006) " with such a giagram the power supply for the circuits is always shown as two vertical lines with the rest of the circuit as horizontal lines. The power lines, or rails as they are often termed, are like the vertical sides ofa ledder with the horizontal circuit lines like the rungs of the ladder. Standar ladder adalah 10 yard panjangnya dengan ukuran kotaknya 18 inchi tetapi dapat mengkontruksi sendiri ladder tersebut dengan menggunakan stick (tongkat) dan tape (pita). Agility ladder (tangga kelincahan) bukan hanya alat yang digunakan untuk mengembangkan kecepatan kaki, ketika digunakan dalam berbagai cara, agility ladder menjadi alat yang multiguna yang fantastis yaitu agility ladder juga sebagai alat untuk meningkatkandaya ledakotot tungkai dan kecepatan.

Pelatihan merupakan proses untuk mencapai prestasi maksimal, tidak hanya mengandalkan bakat dan minat dari atlet tersebut, tetapi harus diikuti dengan pelatihan yang terprogram, berjenjang dan berkelanjutan untuk dapat menghadapi situasi pertandingan dan meningkatkan kemampuan atlet.

Pelatihan menurut Nala (1998) adalah suatu gerakan fisik atau aktivitas mental yang dilakukan secara sistematis dan berulang-ulang dan dalam waktu yang lama dengan pembebanan meningkat secara progresif dan individual yang bertujuan untuk memperbaiki sistem serta fungsi fisiologis 
http://ejurnal.budiutomomalang.ac.id/index.php/ipjok

Jp.jok (Jurnal Pendidikan. Jasmani , Olahraga dan Kesehatan)
Volume 2, Nomor 1, Nov 2018

P-ISSN 2613-9421

E-ISSN 2654-8003

dan psikologis tubuh agar pada waktu melakukan aktivitas olahraga dapat mencapai penampilan optimal.

Daya ledak merupakan kemampuan otot bekerja dengan cepat dan mendadak, ini biasanya dilakukan oleh pelari jarak pendek dan olahraga yang membutuhkan gerakan-gerakan cepat dan mendadak (Roesdiyanto dan Budiwanto, 2008). Jensen dalam (Roesdiyanto dan Budiwanto, 2008) mengatakan bahwa daya ledak merupakan suatu faktor yang sangat penting untuk menghasilkan seorang atlet, bagaimana seorang atlet dapat melempar lebih jauh, dapat melompat lebih tinggi dan dapat berlari lebih cepat, atau seorang perenang dapat berenang dengan cepat, semuanya itu memerlukan kemampuan power (daya ledak otot).

Daya ledak merupakan salah satu unsur kondisi fisik yang memiliki peranan penting dalam aktivitas olahraga, baik sebagai unsur pendukung dalam suatu gerakan maupun unsur utama pencapaian teknik gerakan yang sempurna. Daya ledak merupakan suatu unsur diantara unsur-unsur komponen kondisi fisik yaitu kemampuan biomotorik manusia, yang dapat ditingkatkan sampai batas-batas tertentu dengan melakukan latihan-latihan tertentu yang sesuai dengan cabang olahraga. Oleh karena itu peningkatan maupun pemeliharaannya merupakan dua aspek yang sangat penting yang harus dilakukan secara bertahap. Daya ledak merupakan komponen sangat penting dalam pencapaian prestasi yang lebih baik oleh seorang atlet apabila terus berlatih dengan tekun.

(Sajoto, 1988) menyatakan daya ledak atau power adalah kemampuan melakukan gerakan secara eksplosif. Kemudian (Nala, 1998) menjelaskan daya ledak merupakan salah satu komponen biomotorik yang diidentikkan dengan kekuatan explosive (explosive strength).

Kecepatan merupakan salah satu kemampuan dasar biomotorik yang diperlukan dalam setiap cabang olahraga. Kecepatan adalah kemampuan otot untuk menjawab rangsang dalam waktu sesingkat mungkin (Sukadiyanto dan Muluk, 2011). Sedangkan (Sajoto, 1988), kecepatan (speed) merupakan kemampuan seseorang dalam melakukan gerakan berkesinambungan dalam bentuk yang sama, dalam waktu yang sesingkat-singkatnya. Kecepatan merupakan laju gerakan otot dalam waktu yang singkat, baik untuk bagianbagian tubuh (lengan, tangan, dan tungkai) maupun untuk seluruh tubuh berpindah. Kecepatan sangat tergantung dari kekuatan karena tanpa kekuatan, kecepatan tidak dapat dikembangkan. Jika seorang siswa atau atlet ingin mengembangkan kecepatan maksimalnya maka siswa/atlet juga harus mengembangkan kekuatannya. Selain kekuatan berbagai faktor yang dapat mempengaruhi kecepatan diantaranya yaitu keturunan, umur, masa tubuh elastisitas otot dan jenis otot. 
http://ejurnal.budiutomomalang.ac.id/index.php/jpjok

Jp.jok (Jurnal Pendidikan. Jasmani , Olahraga dan Kesehatan)
Volume 2, Nomor 1, Nov 2018

P-ISSN 2613-9421

E-ISSN 2654-8003

Menurut (Nossek, 1982), kecepatan merupakan kualitas kondisional yang memungkinkan seseorang untuk beraksi secara cepat bila dirangsang untuk melakukan gerakan secepat mungkin. Menurut (Nala, 1998), kecepatan adalah kemampuan untuk berpindah atau bergerak dari tubuh atau anggota tubuh dari satu titik ke titik yang lainnya atau untuk mengerjakan suatu aktivitas berulang yang sama serta berkesinambungan dalam waktu yang sesingkat-singkatnya. (Maksum, 2012) juga mengungkapkan pendapatnya tentang pengertian kecepatan, yaitu kemampuan untuk melakukan gerakan-gerakan yang sejenis secara berturut-turut dalam waktu sesingkat-singkatnya, atau kemampuan untuk menempuh jarak dengan cepat.

\section{METODE}

Jenis penelitian ini adalah kuantitatif dengan metode eksperimen karena mencari hubungan sebab akibat antara dua variabel. Penelitian eksperimen adalah penelitian yang dilakukan secara ketat untuk mengetahui sebab akibat di antara variabel. Salah satu ciri utama dari penelitian eksperimen adalah adanya perlakuan (treatment) (Maksum, 2012). Sedangkan menurut (Arikunto, 1989) penelitian eksperimen merupakan penelitian yang dimaksudkan untuk mengetahui ada tidaknya akibat dari "sesuatu" yang dikenakan pada subjek selidik. Berdasarkan metode eksperimen tersebut, maka digunakan rancangan Matching Only Design (Maksum, 2012)

Adapun pembentukan grup dalam penelitian ini akan membagi tiga kelompok yaitu kelompok eksperimen 1, eksperimen 2, dan kelompok kontrol, maka pairing yang digunakan ialah ordinal pairing. Menurut (Riyanto,2007) ordinal pairing adalah salah satu cara yang digunakan untuk mengelompokkan sampel dengan sistem rangking. Cara ini diselenggarakan dengan menyusun subjek dalam suatu daftar dan mengambil subjek dari atas ke bawah (Hadi, 2004).

Ordinal pairing merupakan memasang-masangkan subjek penelitian atau cara pengelompokkan sampel dengan menggunakan sistem perengkingan, kemudian penempatan sampel pada masing-masing kelompok mengikuti pola "huruf S". Tujuan penggunaan ordinal pairing adalah untuk menyamaratakan kemampuan subjek dimasing-masing kelompok. Maka secara keseluruhan pola yang gigunakan dalam penelitian ini adalah match subject ordinal pairing, (Hadi, 2004).Dalam penelitian ini digunakan teknik analisis data berupa $T$-test. 
http://ejurnal.budiutomomalang.ac.id/index.php/jpjok

Jp.jok (Jurnal Pendidikan. Jasmani , Olahraga dan Kesehatan)
Volume 2, Nomor 1, Nov 2018

P-ISSN 2613-9421

E-ISSN 2654-8003

\section{HASIL DAN PEMBAHASAN}

Hasil analisis secara statistik menggunakan Uji-t sehingga didapatkan data yang bisa dilihat pada data dibawah ini.

Kelompok eksperimen 1

\begin{tabular}{|c|l|c|l|}
\hline Variabel & \multicolumn{1}{|c|}{ Pair } & t-hitung & (2-tailed) \\
\hline Daya Ledak Tungai & Pretes-Posttest & -3.302 & 0,30 \\
\hline Kecepatan & Pretest-Posttest & 1,500 & 0,208 \\
\hline
\end{tabular}

Berdasarkan dari tabel di atas, probabilitas atau tingkat signifikansi dari masing-masing variabel sebesar 0,30 dan 0,208 hal ini berarti $P>$ 0,05.Dengan demikian dapat ditarik kesimpulan bahwa ada perbedaan setelah diberi program latihanladder drill 90 degree rotation. Itu artinya ada pengaruh pelatihan ladder drill 90 degree rotation terhadap peningkatan daya ledak otot tungkai dan kecepatan.

Kelompok eksperimen 2

\begin{tabular}{|c|l|l|l|}
\hline Variabel & Pair & t-hitung & (2-tailed) \\
\hline Daya Ledak Tungkai & Pretest-Posttest & $-1,134$ & 0,253 \\
\hline Kecepatan & Pretest-Posttest & $-.9,223$ & 0.01 \\
\hline
\end{tabular}

Berdasarkan dari tabel di atas, probabilitas atau tingkat signifikansi variabel sebesar 0,253 hal ini berarti $P>0,05$.Dengan demikian dapat ditarik kesimpulan bahwa ada perbedaan setelah diberi program latihanladder drill 90 degree rotation. Itu artinya ada pengaruh pelatihan ladder drill 90 degree rotation terhadap peningkatan daya ledak otot tungkai. Sedangkan kecepatan memiliki 0,01, artinya tidak ada pengaruh untuk kecepatan

Kelompok eksperimen kontrol

\begin{tabular}{|c|l|l|l|}
\hline Variabel & Pair & t-hitung & (2-tailed $)$ \\
\hline Daya Ledak Tungkai & Pretest-Posttest & $-1,600$ & 0,185 \\
\hline Kecepatan & Pretest-Posttest & $-9,096$ & 0.01 \\
\hline
\end{tabular}

Berdasarkan dari tabel di atas, probabilitas atau tingkat signifikansi variabel sebesar 0,185 hal ini berarti $P>0,05$.Dengan demikian dapat ditarik kesimpulan bahwa ada perbedaan setelah diberi program latihanladder drill 90 degree rotation. Itu artinya ada pengaruh pelatihan ladder drill 90 degree rotation terhadap peningkatan daya ledak otot tungkai. Sedangkan kecepatan memiliki 0,01, artinya tidak ada pengaruh untuk kecepatan

Berdasarkan hasil analisis data berupa T-test yang dilakukan pada kelompok eksperimen ladder drill 90 degree rotation dan ladder drill ali shuffle, diperoleh bahwa ada pengaruh yang signifikan terhadap peningkatan daya ledak otot tungkai tetapi tidak ada pengaruh untuk kecepatan pada atlet pencak silat di ranting umum perisai diri 1 lawang. Hasil uji hipotesis pada kelompok kelompok eksperimen ladder drill 90 degree rotation dan ladder drill ali shuffle diperoleh Fhitung lebih besar dari Ftabel, sehingga hipotesis

Shandy Pieter Pelamonia. Pengaruh Pelatihan Ladder Drill 90 Degree Rotation Dan Ladder Drill Ali Shuffle 
http://ejurnal.budiutomomalang.ac.id/index.php/ipjok

Jp.jok (Jurnal Pendidikan. Jasmani , Olahraga dan Kesehatan)
Volume 2, Nomor 1, Nov 2018

P-ISSN 2613-9421

E-ISSN 2654-8003

nihil ditolak. Pelatihan ladder drill 90 degree rotation dan ladder drill ali shufflememiliki pengaruh yang signifikan terhadap daya ledak otot tungkai disebabkan karena intensitas latihan sesuai dengan usia, karakteristik gerakan dan dosis latihan yang sesuai dengan atlet. Tetapi untuk kecepatan tidak ada pengaruh yang signifikan, hal ini disebabkan karenatidak sesuai dengan karakteristik gerakan kecepatan.

Pelatihan ladder drill termasuk latihan yang dapat meningkatkan daya ledak otot tungkai dan kecepatan. Hal ini sesuai dengan penelitian pendapat (Reynolds, 2011) mengatakan bahwa "ladder drills atau tangga latihan adalah cara yang terbaik dan menyenangkan untuk mengajarkan keterampilan gerak. Meskipun gerakan linear dan lateral adalah biomekanik sederhana, dengan kombinasi gerak ini dapat menjadi komplek".

Hasil penelitian ini mendukung penelitian sebelumnya tentang latihan ladder drill (Purnomo, 2016) menyatakan bahwa ada pengaruh latihan ladder drill terhadap kecepatan gerak. Selain itu penelitan (Juliyanto, 2017) menyimpulkan Setelah diberi latihan ladder drill icky shuffle terdapat pengaruh pada peningkatan kecepatan gerak lari40 meter. Dalam penelitian yang lain (Sulistyo, 2016) menjelaskan bahwa latiha Plyometric front cone hops dan lateral hops memberikan pengaruh terhadap daya ledak otot tungkai dan kelincahan. (Koestanto, S.H dkk, 2017), (Kusuma, K.C.A dan Kardiawan, I.K.H, 2017), (Irawan, R, 2014) dan

\section{SIMPULAN}

Berdasarkan hasil penelitian dan pembahasan yang telah diuraikan pada bab sebelumnya, maka dapat disimpulkan bahwa: Terdapat pengaruh yang signifikan pelatihan ladder drill 90 degree rotation dan ali shuffle terhadap peningkatan daya ledak otot tungkai dan ada peningkatan kecepatan tetapi tidak signifikan untuk atlet pencak silat di ranting umum Perisai Diri 1 Lawang di Kecamatan Lawang, Kabupaten Malang.

Sesuai dengan hasil penelitian, maka saran yang dapat disampaikan antara lain: Untuk meningkatkan daya ledak otot tungkai dapat dilakukan dengan latihan ladder drill 90 degree rotation dan ali shuffle tetapi tidak disarankan untuk melatih kecepatan. Sehingga dapat menjadikan kedua bentuk latihan ini sebagai acuan dalam upaya untuk meningkatkan daya ledak otot tungkai Perlu diadakan penelitian lebih lanjut terkait dengan perbandingan latihan ladder drill 90 degree rotationdan ali shuffle, dengan menambah model latihan lain seperti kombinasi latihan plyometric pada populasi dan karakteristik yang berbeda, dengan harapan agar nantinya memberikan hasil yang lebih luas terkait dengan hasil latihan tersebut. Bagi peneliti selanjutnya, penelitian ini dapat dijadikan sebagai bahan masukan 
maupun perbandingan, jika peneliti selanjutnya ingin mengangkat masalah yang sejenis.

\section{DAFTAR PUSTAKA}

Arikunto, Suharsimi. 1989. Manajemen Penelitian. Jakarta: Departemen Pendidikan dan Kebudayaan, Direktorat Jenderal Pendidikan Tinggi, PPLPTK.

Bolton, B. 2006.Ladder and Functional Block Programing. Jurnal of Sports Science and Medicine: Chappter 11

Bompa, and Haff,G, 2009. Theoryand Methodology ofTraining. United States : Human Kinetics

Hadi, S. 2004. “Metodelogi Research”. Yogyakarta: Andi

Irawan, R. 2014. Hubungan Kelentukan Togok, Daya Ledak Otot Tungkai, Dan Kekuatan Otot Tungkai Terhadap Servis Slice Tenis Lapangan. Journal of Physical Education, Health and Sport. 1 (2) (2014)

Juliyanto, O.D. Pengaruh latihan ladder drill icky shuffle terhadap peningkatan kecepatan. Jurnal Kesehatan. Vol. 07 No. 3 Edisi Maret 2017 Hal $(45-52)$

Kusuma, K.C.A dan Kardiawan, I.K.H. 2017. Effect of Ladder Drill Exercise on Speed, Surrounding, and Power Leg Muscle. Journal of Physical Education, Sport, Health and Recreations. 6 (3) (2017) 193 - 196

Komang Ayu Tri Widhiyanti dkk.2013. Pelatihan Pliometrik Alternate Leg Bound Dan Double Leg Bound Meningkatkan Daya Ledak Otot Tungkai Pada Siswa Putra Kelas Vii Smp Negeri 3 Sukawati Tahun Pelajaran 2012/2013. Sport and Fitness Journal Volume 1, No. 2 : 19 - 26, Nopember 2013

Maksum, A. 2012. Metodologi Penelitian dalam Olahraga. Surabaya: Unesa University Press

Nala. N. 1998. Prinsip Pelatihan Fisik Olahraga. Denpasar: Universitas Udayana 
Nossek, J. 1982. “General Theory of Training”. Lagos: Pan African Press. Ltd. In Furqon (Ed). Teori Umum Latihan. Surakarta

Purnomo, H. 2016. Pengaruh Latihan Ladder Drill Two Feet Each Square Terhadap Peningkatan Kecepatan Gerak.Jurnal Kesehatan Olahraga Vol. 06 No 2 edisi Oktober 2016 hal 354-357

Reynold, Tony. 2011. The ultimate agylity ladder guide. (Online). http://www.footballgc.com.au/uploads/files/Tony_Raynold_Ultimate_Agylit y_Ladder_Guide.pdf.

Riyanto, Y. 2007. Metodologi Penelitian Pendidikan Kualitatif dan Kuantitatif. Surabaya: Unesa University Press

Roesdiyanto dan Budiwanto, S. 2008. Dasar-dasar Kepelatihan Olahraga. Malang: Laboratorium Ilmu Keolahragaan, Jurusan Ilmu Keolahragaan, Universitas Negeri Malang

Sajoto, M. 1995. Peningkatan dan Pembinaan Kondisi Fisik dalam Olahraga. Semarang: Dahara Prize.

Sajoto, M. 1988. Pembinaan Kondisi Fisik dan Olahraga. Jakarta: Depdikbud

Sukadiyanto dan Muluk, D. 2011. Pengantar Teori dan Metodologi Melatih Fisik. Bandung: Lubuk Agung.

Sulistyo, Y.W. pengaruh latihan plyometric front cone hops dan lateral hop terhadap penginkatan daya ledak otot tungkai dan kecepatan. Bravo's Jurnal Volume 4 No. 3 Tahun 2016 hal 142-155.

Koestanto, S.H dkk, 2017. Model Comparison Exercise Circuit Training Game and Circuit Ladder Drills to Improve Agility and Speed. Journal of Physical Education, Health and Sport. 4 (2) (2017) 78-83

Tsivkin, Troman. 2011. http: //www.sport-fitness-advisor.com. di unduh tanggal 6 Februari 2018

Young, W. B., \& Sheppard, J.M. 2006. Agility Literature Review: Classifications, Training and Testing. Journal of Sports Sciences. 